\title{
How the activity of cyclic AMP-dependent protein kinase A may be influenced by stress
}

\author{
A. Ostrowska' \\ The Kielanowski Institute of Animal Physiology and Nutrition, \\ Polish Academy of Sciences \\ 05-110 Jabtonna, Poland
}

(Received 19 April 1999; accepted 8 May 2000)

ABSTRACT

The binding of $\left[{ }^{3} \mathrm{H}\right] \mathrm{cAMP}$ to cytosol and membrane fractions of the anterior pituitary of sheep exposed to mild electrical stress was investigated. The fractions were incubated with different concentrations $(10-200 \mathrm{nM})$ of $\left[{ }^{3} \mathrm{H}\right] \mathrm{cAMP}$; the bound ligand was precipitated with ammonium sulphate and isolated on Millipore filters. [ $\left.{ }^{3} \mathrm{H}\right] \mathrm{cAMP}$ binding was evaluated by Scatchard analysis. In control animals, the dissociation constant $\left(\mathrm{K}_{\mathrm{p}}\right)$ was $29.13 \pm 3.41 \mathrm{nM}$ and $21.2 \pm 2.0 \mathrm{nM}$ in membrane and cytosol fractions, respectively. In the membrane fraction, one-day stress decreased $\mathrm{K}_{\mathrm{D}}$ to $12.42 \pm 1.64$ $n M$, whereas prolongation of stress to three days resulted in a return of $\mathrm{K}_{\mathrm{b}}$ to control levels. Stress had no influence on the $K_{D}$ in cytosol fractions. The maximal binding activity $\left(\mathrm{B}_{\max }\right.$ ) of [ $\left.\mathrm{H}\right] \mathrm{cAMP}$ was about three-fold higher in the membrane fraction ( $148.4 \pm 12.0 \mathrm{pmol} /$ pituitary) than in the cytosol $(45.00 \pm 1.25 \mathrm{pmol} / \mathrm{pituitary})$ in unocstrous, untreated cwes. One-day stress exposure resulted in a decrease in $\mathrm{B}_{\max }$ of $\left[{ }^{3} \mathrm{H}\right] \mathrm{cAMP}$ in membrane and cytosol fractions. Prolongation of stress to three days caused a return of $B_{\text {In:x }}$ to near control levels in both fractions. These results indicate that, in the anterior pituitary gland, stress may infiuence, probably via hormonal stimulations, the activity of protein kinase $\Lambda$ through modifying the affinity of its regulatory subunit for cAMP and regulatory subunit contents. The membrane-bound regulatory subunit of protein kinase $\Lambda$ is three-fold more abundant than the cytosolic regulatory subunit.

KEY WORDS: $\left[{ }^{3} \mathrm{H}\right] \mathrm{cAMP}$ binding, anterior pituitary, sheep

\footnotetext{
'Present address: Institute of Ecology, Polish Academy of Sciences, Konopnickiej 1, Dziekanów Leśny ncar Warsaw, 05-092 komianki, Poland
} 


\section{INTRODUCTION}

Protein kinase A (adenosine $3^{\prime}, 5^{\prime}$-monophosphate-dependent protein kinase; ATP-protein phosphotransferase; EC 2.7.1.37) mediates the effects of cAMP. The enzyme is involved in many biochemical processes, influencing the basal metabolism, growth, development, differentiation, and proliferation of the cell.

Protein kinase $A$ is activated by binding cAMP to its regulatory (R) subunit, dissociation of the holoenzyme and liberation of the catalytic $(C)$ subunit. The binding of $\left[{ }^{3} \mathrm{H}\right] \mathrm{cAMP}$ reflects the contents of the $\mathrm{R}$ of protein kinase $\mathrm{A}$. The liberation of subunit $C$ uncovers its active center and transfers the phosphate from ATP to the protein substrate. The activity of protein kinase A depends on the cellular concentration of cAMP, proportions and combinations of holocnzyme subunits and compartmentalization in the cell (Ostrowska, 2000).

In the anterior pituitary gland, the activity of protein kinase $\mathrm{A}$ is regulated by hormones and neurohormones; cAMP may mediatc enzyme activation through diverse pathways. Dibutyryl cAMP, estradiol and progesterone influence the protein kinase A inhibitor level and change the activity of pituitary protein kinase A (Ostrowska et al., 1984; Ostrowska and Kochman, 1990; Ostrowska, 1994). The exposure of animals to stress results in augmented transmission of neurohormones that activate adenylyl cyclase directly or indirectly and increase cAMP synthesis (Guild and Reisine, 1987; Levin and Roberts, 1991). Cyclic AMP directly activates protein kinase $A$ and may have an additional, indirect effect on enzyme activity. The aim of this work was to study how the activity of protein kinase A can be influenced by stress. The results indicate that the activity of protein kinase A may be modified by changes in the affinity of its regulatory subunit for cAMP and its contents.

\section{MATERIAL AND METHODS}

\section{Treatment of animals}

Adult Polish Merino anoestrous ewes were used for the experiment. The animals were maintained in separate boxes under natural light conditions in March. The ewes were subjected to mild electrical foot-shock stress stimulation according to Przekop et al. (1985) and Domański et al. (1992). Mild electrical pulses (3 mA) were applied for $20 \mathrm{~min}$ during onc $\mathrm{h}$, followed by a $40 \mathrm{~min}$ interval without stress stimulation; this pattern continued for $9 \mathrm{~h}$ daily through one or three consecutive days. This is a type of psychical stress (Domański et al., 1992). The animals became anxious at the first moment of stressing, however, after some time they settled down and showed no fear. The ewes of the control group were kept in the boxes without stress stimulation. 


\section{Assay of $\left[{ }^{3} H\right]$ cAMP binding}

The anterior lobes of the pituitaries were isolated on ice and used directly for the experiment or stored in liquid nitrogen. All procedures were carried out at $4^{\circ} \mathrm{C}$. The pituitaries were minced and homogenized in 5 vol of $10 \mathrm{mM}$ Tris buffer. $\mathrm{pH}$ 7.4. The homogenate was poured through two layers of cheese cloth and centrifuged at $1500 \mathrm{x}$ g for $5 \mathrm{~min}$. The supcrnatant was centrifuged at $10000 \mathrm{x} \mathrm{g}$ for 20 min to pellet membranes. The membranes were washed twice and resuspended in the same buffer to a final membrane protein concentration (Bradford, 1976) of $2-3 \mathrm{mg} / 100 \mu \mathrm{l}$, for storage. The supernatant was centrifuged once at $20000 \mathrm{xg}$ for $20 \mathrm{~min}$ and once more at $100000 \mathrm{xg}$ for $1 \mathrm{~h}$ to obtain a cytosol fraction. The cytosol and membrane fractions were used on the day of preparation or after freezing in liquid nitrogen and storage.

Cyclic AMP binding activity was determined similarly to the procedure presented by Doskeland and Ogreid (1981) and Moore et al. (1983). Triplicate samples, in a total volume of $100 \mu \mathrm{l}$ containing $200 \mu \mathrm{g}$ of cytosolic protein or $50 \mu \mathrm{g}$ of membrane protein were incubated at $25^{\circ} \mathrm{C}$ for $45 \mathrm{~min}$ in $50 \mathrm{mM}$ sodium/potassium phosphate, pH 6.5, $100 \mathrm{mM} \mathrm{NaCl}, 0.5 \mathrm{mM}$ 3-isobutyl-1-methylxanthine (Sigma) with [ $\left.{ }^{3} \mathrm{H}\right] \mathrm{cAMP}$ (Amersham Int., $28 \mathrm{Ci} / \mathrm{mmol}, 1 \mathrm{mCi} / \mathrm{ml}$ ) at various concentrations (10 to $200 \mathrm{nM}$ ) of labeled cyclic nucleotide and with a fixed amount of it for determination of standard binding conditions. The reaction was stopped by adding $0.5 \mathrm{ml}$ of icc-cooled saturated ammonium sulphate. Precipitates were collected on $0.5 \mu \mathrm{m}$ HAWP Millipore filters, rinsed twice with $1 \mathrm{ml}$ ice-cooled, saturated ammonium sulphate and counted by standard scintillation techniques. Nonspecific binding was assessed in identical assays containing 1000-fold excess of unlabeled cAMP. Specific binding was detcrmincd as the difference between total binding and nonspecific binding.

Scatchard analysis of cAMP binding was conducted according to Reitherman et al. (1981) and Moore et al. (1983). The calculations were made using the Statgraphics Program. Data are means \pm SE $(n=9-11)$ of the values obtained in triplicate measures of membranc or cytosol preparations obtained from 5-6 pooled anterior pituitary glands.

\section{RESULTS}

$\left.{ }^{3} \mathrm{H}\right]$ cAMP bound specifically to the cytosol fraction of anterior pituitary of sheep. Eighty nM $\left[{ }^{3} \mathrm{H}\right] \mathrm{CAMP}$, in a volume of $0.1 \mathrm{ml}$ were completely bound by $200 \mathrm{\mu g}$ of cytosol protein at $25^{\circ} \mathrm{C}$ in $45 \mathrm{~min}$; binding did not change during $2 \mathrm{~h}$ of incubation. $\left[{ }^{3} \mathrm{H}\right] \mathrm{cAMP}$ binding was protein-dependent. Specific binding increased in the protein concentration range of $0-200 \mu \mathrm{g}$ in the cytosol fraction and $0-50 \mu \mathrm{g}$ 
in the membrane fraction, in a total volume of $0.1 \mathrm{ml}$ when $10 \mathrm{nM}\left[{ }^{3} \mathrm{H}\right] \mathrm{cAMP}$ were used for incubation. Nonspecific binding increased linearly at higher protein concentrations. The specificity of $\left[{ }^{3} \mathrm{H}\right] \mathrm{cAMP}$ binding to anterior pituitary cytosol was determined by measuring the inhibition of $10 \mathrm{nM}\left[{ }^{3} \mathrm{H}\right] \mathrm{cAMP}$ binding by various concentrations of unlabeled cAMP and cGMP. Half maximum inhibition $\left(\mathrm{IC}_{50}\right)$ occurred with $200 \mathrm{nM}$ of unlabeled cAMP and 13,750 nM cGMP.

Figure 1 presents Scatchard plot analyses of $\left[{ }^{3} \mathrm{H}\right] \mathrm{cAMP}$ binding by cytosolic (A) and membrane (B) fractions of the control group of animals. The Scatchard plots of $\left[{ }^{3} \mathrm{H}\right]$ cAMP binding were linear for cytosol $(r=0.96)$ and membrane $(\mathrm{r}=0.95)$ fractions. The $\mathrm{B}_{\max }$ of $\left[{ }^{3} \mathrm{H}\right] \mathrm{cAMP}$ binding to the membrane fraction was about three times higher than to the cytosol fraction, in unoestrous, untreated sheep.
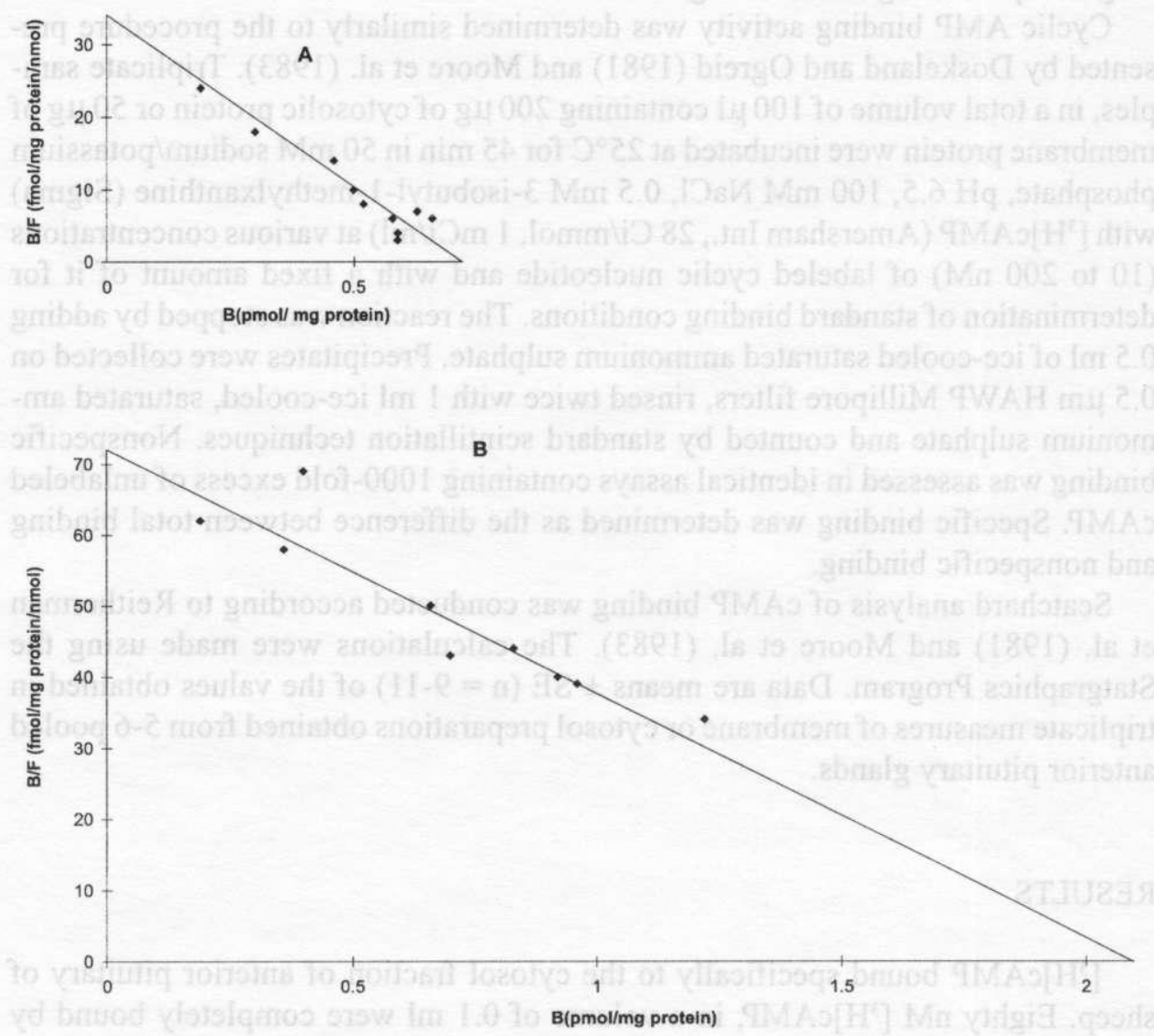

Figure 1. The Scatchard plot analyses of $\left[{ }^{3} \mathrm{H}\right] \mathrm{cAMP}$ binding to cytosolic (A) and membrane (B) proteins of anterior pituitary of sheep. $200 \mu \mathrm{g}$ of cytosol or $50 \mu \mathrm{g}$ of membrane fractions were incubated at $25^{\circ} \mathrm{C}$ during $45 \mathrm{~min}$ with different concentrations of [ $\left.{ }^{3} \mathrm{H}\right] \mathrm{cAMP}(10-100 \mathrm{nM})$ 
The influence of stress on $\left[{ }^{3} \mathrm{H}\right] \mathrm{cAMP}$ binding by the cytosol fraction is presented in Table 1 and Figure 2. The exposure of ewes to stress resulted in changes in the maximal binding activity $\left(\mathrm{B}_{\max }\right.$, or capacity of binding) of $\left[{ }^{3} \mathrm{H}\right] \mathrm{cAMP}$. One day of stress significantly decreased $\mathrm{B}_{\max }$ of $\left[{ }^{3} \mathrm{H}\right] \mathrm{cAMP}$, whereas prolongation of stress stimulation to three days brought about the return of $\mathrm{B}_{\max }$ to control values. Stress did not change the affinity of $\left[{ }^{3} \mathrm{H}\right] \mathrm{cAMP}$ binding to the cytosolic fraction. Three days of stress resulted in a tendency towards decreased dissociation constant $\left(\mathrm{K}_{\mathrm{D}}\right)$ the changes were not statistically significant.

The binding of $\left[{ }^{3} \mathrm{H}\right]$ cAMP to membrane fractions is presented in Table 2 and Figure 3. The exposure of animals to stress resulted in changes in the capacity and affinity of $\left[{ }^{3} \mathrm{H}\right] \mathrm{cAMP}$ binding. One day of stress caused a nearly 3 -fold decrease in the capacity of $\left[{ }^{3} \mathrm{H}\right] \mathrm{cAMP}$ binding (Table 2 , decrease in $\mathrm{B}_{\max }$ ) and about a 2.5 -fold, decrease in $\mathrm{K}_{\mathrm{D}}$. The prolongation of stress to three days resulted in increased binding capacity. This value was still lower than in control, in rclation to protein con-

TABLE 1

Maximal binding activity $\left(\mathrm{B}_{\text {max }}\right)$ and dissociation constant $\left(\mathrm{K}_{\mathrm{D}}\right)$ of $\left[{ }^{3} \mathrm{H}\right] \mathrm{CAMP}$ binding to the cytosol of anterior pituitary of sheep exposed to stress

\begin{tabular}{lccc}
\hline & \multicolumn{2}{c}{$\mathrm{B}_{\mathrm{mul}_{\mathrm{i}}}$} & $\mathrm{K}$ \\
\cline { 2 - 4 } Group of animals & pmol/pituitary & $\mathrm{pmol} / \mathrm{mg}$ protein & $\mathrm{nM}$ \\
\hline Control, without stress & $45.00 \pm 1.25$ & $0.72 \pm 0.02$ & $21.2 \pm 2.0$ \\
One day stress & $24.02 \pm 3.23^{\mathrm{a}}$ & $0.52 \pm 0.07^{\mathrm{a}}$ & $21.0 \pm 7.8$ \\
Three day, stress & $50.88 \pm 3.08^{\mathrm{b}}$ & $0.66 \pm 0.04^{\mathrm{h}}$ & $15.9 \pm 5.1$ \\
\hline
\end{tabular}

Results were obtained from saturation experimernts and Scatchard analyses of the data. Values arc expressed as the means $\pm S E(n=9)$ from triplicate measures in cytosolic preparations obtained from 5-6 pooled pituitary glands. ", significant difference from control; ", significant difference from one day stressed animals at $\mathrm{P}<0.01$ at least

TABLE 2

Maximal binding activity $\left(\mathrm{B}_{\text {miax }}\right)$ and dissociation constant $\left(\mathrm{K}_{\mathrm{p}}\right)$ of $\left[{ }^{3} \mathrm{H}\right] \mathrm{cAMP}$ binding to the membranes of anterior pituitary gland of sheep exposed to stress

\begin{tabular}{lccc}
\hline \multirow{2}{*}{ Group of animals } & \multicolumn{2}{c}{$\mathrm{B}_{\text {min }}$} & $\mathrm{K}_{\mathrm{v}}$ \\
\cline { 2 - 3 } & $\mathrm{pmol} /$ pituitary & $\mathrm{pmol} / \mathrm{mg}$ protein & $\mathrm{nM}$ \\
\hline Control, without stress & $148.4 \pm 12.0$ & $2.10 \pm 0.17$ & $29.13 \pm 3.41$ \\
One day, tress & $43.6 \pm 3.0$ & $0.73 \pm 0.05^{\mathrm{s}}$ & $12.42 \pm 1.64^{\mathrm{i}}$ \\
Three day, stress & $148.1 \pm 20.1^{\mathrm{b}}$ & $1.62 \pm 0.22^{\mathrm{ih}}$ & $26.19 \pm 5.43^{\mathrm{b}}$ \\
\hline
\end{tabular}

Results were obtained from saturation experiments and Scatchard analyses of the data. Data are the mcan $\pm S E(n=10-11)$ of the values obtained in triplicate measures on 5-6 pooled anterior pituitary glands. ", significant difference from control; ${ }^{~}$, significant difference from one day stressed animals at $\mathrm{P}<0.01$ at least 

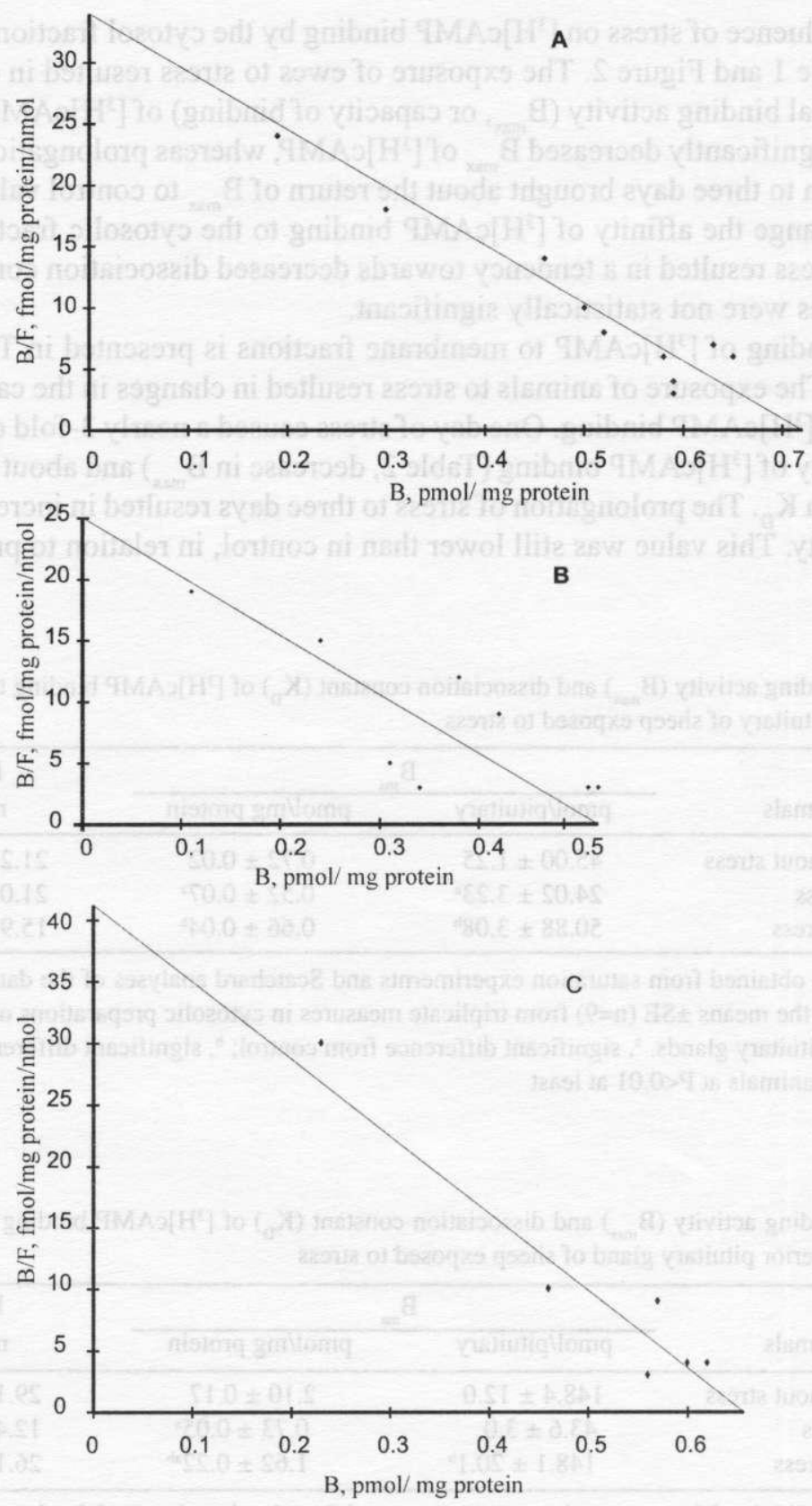

Figure 2. The Scatchard plot analyses of $\left[{ }^{3} \mathrm{H}\right] \mathrm{cAMP}$ binding to cytosol fractions of anterior pituitary of sheep. The influence of stress. A, control group of animals; B, one day stressed animals; C, three day stressed animals 


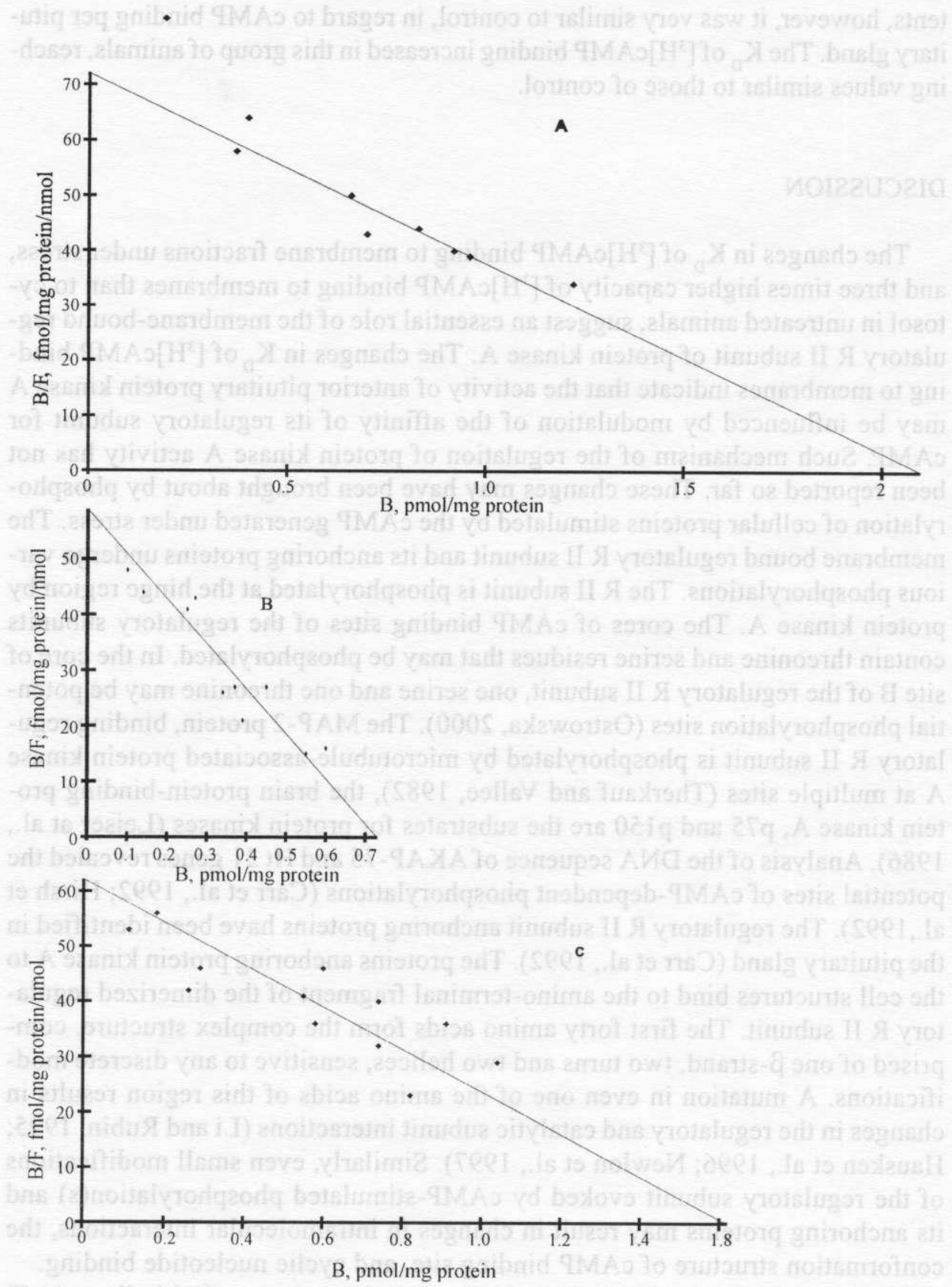

Figure 3. The Scatchard plot analyses of $\left[{ }^{3} \mathrm{H}\right] \mathrm{cAMP}$ binding to membrane fraction of anterior pituitary of sheep. The influence of stress. A, control group of animals; B, one day stressed animals; C, three day stressed animals 
tents, however, it was very similar to control, in regard to cAMP binding per pituitary gland. The $\mathrm{K}_{\mathrm{D}}$ of $\left[{ }^{3} \mathrm{H}\right] \mathrm{cAMP}$ binding increased in this group of animals, reaching values similar to those of control.

\section{DISCUSSION}

The changes in $\mathrm{K}_{\mathrm{D}}$ of $\left[{ }^{3} \mathrm{H}\right] \mathrm{cAMP}$ binding to membrane fractions under stress, and three times higher capacity of $\left[{ }^{3} \mathrm{H}\right] \mathrm{cAMP}$ binding to membranes than to cytosol in untreated animals, suggest an essential role of the membrane-bound regulatory R II subunit of protein kinase A. The changes in $K_{D}$ of $\left[{ }^{3} \mathrm{H}\right] \mathrm{cAMP}$ binding to membranes indicate that the activity of anterior pituitary protein kinase $A$ may be influenced by modulation of the affinity of its regulatory subunit for cAMP. Such mechanism of the regulation of protein kinase A activity has not been reported so far. These changes may have been brought about by phosphorylation of cellular proteins stimulated by the cAMP generated under stress. The membrane bound regulatory R II subunit and its anchoring proteins undergo various phosphorylations. The R II subunit is phosphorylated at the hinge region by protein kinase $\mathrm{A}$. The cores of cAMP binding sites of the regulatory subunits contain threonine and serine residues that may be phosphorylated. In the core of site $B$ of the regulatory R II subunit, one serine and one threonine may be potential phosphorylation sites (Ostrowska, 2000). The MAP-2 protein, binding regulatory R II subunit is phosphorylated by microtubule-associated protein kinase A at multiple sites (Therkauf and Vallee, 1982), the brain protein-binding protein kinase A, p75 and p150 are the substrates for protein kinases (Leiser at al., 1986). Analysis of the DNA sequence of AKAP-75 and Ht 31 genes revealed the potential sites of cAMP-dependent phosphorylations (Carr et al., 1992; Hirsh et al.,1992). The regulatory $\mathrm{R}$ II subunit anchoring proteins have been identified in the pituitary gland (Carr et al., 1992). The proteins anchoring protein kinase A to the cell structures bind to the amino-terminal fragment of the dimerized regulatory R II subunit. The first forty amino acids form the complex structure, comprised of one $\beta$-strand, two turns and two helices, sensitive to any discrete modifications. A mutation in even one of the amino acids of this region results in changes in the regulatory and catalytic subunit interactions ( $\mathrm{Li}$ and Rubin, 1995; Hausken et al., 1996; Newlon et al., 1997). Similarly, even small modifications of the regulatory subunit evoked by cAMP-stimulated phosphorylation(s) and its anchoring proteins may result in changes in intramolecular interactions, the conformation structure of cAMP binding site, and cyclic nucleotide binding.

The regulatory subunit of protein kinase $A$ is the main protein-binding CAMP in mammals, and the only one in the anterior pituitary gland. So far, four isoforms of the regulatory subunit of protein kinase A have been identified in mam- 
mals. Each of them has two cAMP binding sites, thus, a complex Scatchard plot could have been expected. Instead, a linear plot was obtained under the studied conditions, with a dissociation constant in the range of 10-30 nM. The linearity of Scatchard plots and similar $\mathrm{K}_{\mathrm{D}}$ values of cAMP binding have been demonstrated in other mammals. The cAMP was bound to the regulatory subunit of protein kinase A with affinities corresponding to $\mathrm{K}_{\mathrm{D}}$ of : $0.24 ; 4.0 ; 6.0 ; 7.7$ and $11.3 \mathrm{nM}$ in different preparations of mammalian tissues (Doskeland and Ogreid, 1981; Reitherman et al., 1981; Moore et al., 1983). Positive cooperation between sites on the same regulatory subunit is known to linearize the Scatchard plot (Buss et al., 1979; Doskcland and Ogreid, 1981). The regulatory R I subunit is generally solubilized in the cytoplasm (Meinkoth et al., 1990), however, in certain specialized cells, such as human erythrocytes or T-lymphocytes, it may be associated with the anchoring proteins (Rubin, 1994; Skalhegg et al., 1994). The regulatory R II subunit has been found only in particulate fractions (Nigg et al., 1985; Dell Acqua and Scott, 1997; Colledge and Scott, 1999). Moreover, the $\mathrm{K}_{\mathrm{D}}$ of the regulatory $\mathrm{R} \mathrm{I}$ subunit and anchoring proteins is in the micromolar range, while the $K_{D}$ of the regulatory $R$ II subunit is in the nanomolar range (Colledge and Scott, 1999). Thus, the above results presenting the binding of $\left[{ }^{3} \mathrm{H}\right]$ cAMP to cytosol and membrane fractions are supposed to be representative for binding of the cyclic nucleotide to R I and R II subunits of protein kinase A, respectively.

The maximal activity of $\left[{ }^{3} \mathrm{H}\right] \mathrm{cAMP}$ binding is about three-fold higher in the membranes than in the cytosol fraction (Tables 1 and 2; Figure 1). The values of $\mathrm{B}_{\max }$ are in a similar range as those found in human placental cytosol and bovine adrenal cortex cytosol and membranes (Reitherman et al., 1981; Moore et al., 1983). So the high capacity of $\left[{ }^{3} \mathrm{H}\right]$ cAMP binding to the membrane fraction suggests a special role for the membrane regulatory $R$ II subunit of protein kinase $A$. The protein kinase II is associated with cellular structures through the regulatory R II subunit bound to multivalent anchoring proteins and different protein kinases, phosphatases, activators, inhibitors, substrates and enzymes modifying their activity (Colledge and Scott, 1999). The membrane bound regulatory R II subunit is suggested to be involved in the regulation of transcription. The overexpression of a truncated AKAP 75 that did not bind the regulatory R II subunit to cellular membranes, resulted in the transport of the R II subunit to the cytoplasm which prevented the activation of transcription (Feliciello et al., 1996). The membrane-bound protein kinase A may be involved in secretion processes. In the pancreatic islets, the damage of the regulatory R II subunit binding to membranes by disruption of anchoring proteins reduced the glucagon-like peptide stimulated secretion of insulin from clonal $\beta$-cells. The level of secretion was restored after regulatory R II subunit targeting by the expression of anchoring proteins (Lester et al., 1997). Thus, it seems possible that such high capacity of $\left[{ }^{3} \mathrm{H}\right] \mathrm{cAMP}$ binding found in the 
membranes may be associated with a special role of the R II subunit of protein kinase $\mathrm{A}$ in pituitary hormone synthesis and secretion.

The changes in the capacity of [ $\left.{ }^{3} \mathrm{H}\right] \mathrm{cAMP}$ binding to membrane and cytosol fractions, evoked by stress indicate that the activity of protein kinase A may be modulated by the modifications of regulatory subunit contents. Cylic AMP influences the protein kinase A subunit levels in anterior pituitary cell cultures. The activation of adenylyl cyclase by forskolin or pituitary adenylyl cyclase activating peptide 38 has resulted in a decrease in R I and R II subunit contents (McArdle and Counis, 1996; Garrel et al., 1997). The addition of 8-Br-cAMP into anterior pituitary cell culture has been found to increase the R II subunit contents (Garrel et al., 1995). On the other hand, the decrease in [ $\left.{ }^{3} \mathrm{H}\right] \mathrm{cAMP}$ binding found in membrancs and cytosol after one day of stress may have been a result of the occupation of the regulatory subunit by stress-generated cAMP. Recently, the regulatory R II $\beta$ subunit has been suggested to be transported into the cell nucleus, where it may play the role of cAMP response element activator (Srivastava et al., 1998). The protein anchoring the regulatory R Il subunit has been found in cell nucleus (Coghlan et al., 1994), which supports this suggestion. On the other hand, cAMP is known to increase the contents of protein kinase A subunit mRNAs and proteins in endocrine tissues (Ratoosh et al., 1987; Oyen et al., 1988; Landmark et al., 1991). In the anterior pituitary gland, cAMP increases mRNA contents of the regulatory $\mathrm{R}$ II $b$ subunit (Garrel ct al., 1993). The sequences activated by cAMP have been found in the promoter region of the regulatory R II $\beta$ subunit (Kurten et al., 1992; Singh ct al., 1991). The prolongation of stress results in the decrease in corticotropin releasing factor receptors and cAMP synthesis (Rivier and Vale, 1987). Thus, the modification of the capacity of $\left[{ }^{3} \mathrm{H}\right] \mathrm{cAMP}$ binding to membrane and cytosol fractions may have been caused by stress stimulated changes in pituitary cAMP levels, followed by modulation of R I and R II subunit contents.

The modifications of pituitary protein kinase A activity are supposed to be associated with the regulation of hormone synthesis and release. Protcin kinase A is involved in the regulation of gene expression via phosphorylation and activation of CREB (cAMP response element binding protein) or AP-2 (activator protein 2), the transcription factors activating promoter cAMP response sequences, which is followed by the recruitment of basal transcription factors and polymerase II RNA to the gene promoter and activation of transcription (Ostrowska, 2000). The sequences activated through cAMP have been found in the 5'-flanking regulatory regions of the genes for growth hormone, prolactin, vasoactive intestine peptide, luteinizing hormone, somatostatin, proopiomelanocortin and enkephalin (Roesler et al., 1988; Levin and Roberts, 1991). The cAMP activates the release of luteinizing hormone, prolactin and growth hormone from the anterior pituitary gland and from anterior pituitary-derived cells (Sundberg et al., 1976; Puttagunta et al., 1992; Counis et al., 1993; Inukai et al., 1993). Thus, the changes in $\left[{ }^{3} \mathrm{H}\right] \mathrm{cAMP}$ binding 
activity are supposed to be associated with modifications of the activity of protein kinase $\mathrm{A}$ and are thought to affect intracellular signaling and cell responsiveness to hormones and participate in a subtil manner in the regulation of anterior pituitary hormone synthesis and release.

\section{CONCLUSIONS}

In the anterior pituitary gland, the activity of $\left[{ }^{3} \mathrm{H}\right] \mathrm{cAMP}$ binding to membrane and cytosol fractions is influenced by stress stimulation, which suggests the modification of the activity of membrane and cytosolic protein kinase A.

The changes in $\mathrm{K}_{\mathrm{D}}$ of $\left[{ }^{3} \mathrm{H}\right] \mathrm{cAMP}$ binding to membrane fractions suggest that hormonal stimulations influence the affinity for cAMP of the regulatory subunit of protein kinase $\mathrm{A}$.

The $\left[{ }^{3} \mathrm{H}\right] \mathrm{cAMP}$ binding activity is three-fold higher in membranes than in the cytosol, which indicates an essential role of the membrane-bound R II subunit of protein kinase $\mathrm{A}$.

The changes in $\mathrm{B}_{\max }$ of $\left[{ }^{3} \mathrm{H}\right] \mathrm{cAMP}$ suggest of the modifications of contents of the regulatory subunits of protein kinase $A$.

The changes in $\left[{ }^{3} \mathrm{H}\right]$ cAMP binding activity are supposed to be associated with stress-stimulated modulations of protein kinase A activity, and cAMP-dependent regulation of anterior pituitary hormone synthesis and release.

\section{ACKNOWLEDGEMENTS}

I wish to thank Prof. Dr. Raymond Counis for discussion of the results, Prof Dr. Franciszek Przckop for the pituitary glands and making it possible to carry out this work in his laboratory, and to Prof. Dr. Henryk Fandrejewski and Dr. Stanisława Raj for help in the calculations and statistical analyses.

\section{REFERENCES}

Bradford M.M., 1976. A rapid and sensitive method for the quantification of microgram quantities of protein utilizing the principle of protein of dye-binding. Aral. Biochem. 72, 248-254

Buss J.E., McCune R.W., Gill G.N., 1979. Comparison of cyclic nucleotide binding to adenosine 3',5'-monophosphate and guanosine 3',5'-monophosphate-dependent protein kinases. J.Cycl. Nucl. Res. 5. 225-237

Carr D.W., Hausken Z.E., Fraser I.D.C., Stofko-Hahn R.E., Scott J.D., 1992. Association of the type II cAMP-dependent protein kinase with a human thyroid RII-anchoring protein. J. Biol. Chem. 267. $13376-13392$ 
Coghlan V.M., Langeberg L.L... Fernandez A., Lamb N.J.C., Scott J.D., 1994. Cloning and characterization of AKAP 95, nuclear protein that associates with the regulatory subunit of type II camp-dependent protein kinase. J. Biol. Chem. 269, 7658-7665

Colledge M., Scott J.D., 1999. AKAPs: from structure to function. Compartmentalization of signaling molecules through association with anchoring proteins. Trends Cell Biol. 8, 216-221

Counis R., Bouamound N., Lerrant Y., Starzec A., Moumni M., Kottler M.L., Garrel G., Berault A., Bergametti F., 1993. Donnecs recent sur le recepteur de la gonadoliberine et les mechanismes de controle par le neuropeptide de l'expression des genes des hormones gonadotropes. Contracept. Fertil. Sex. 21, 773-779

Dell' Acqua M.L.. Scott J.M., 1997. Protein kinase A anchoring. J. Biol. Chem. 272. 12881-12884

Domański E., Ostrowska A., Rutkowski J., Luboińska U., 1992. The dynamics of $\beta$-endorphin release by the hypothalamic nuclei and pituitary gland in sheep under physiological and stress conditions. Exp. Clin Endocrinol. 99, 39-44

Doskeland S.O., Ogreid D., 1981. Binding proteins for cyclic AMP in mammalian tissues. Int. J. Biochem. 13, I-19

Feliciello A., Giuliano P., Porcellini A., Garbi C., Obici S., Mcle E., Angotti E., Gricco D., Amabile G., Cassano S., Li Y., Musti A.M., Rubin C.S. Gottesman M.E., Avvedimento E.V., 1996. The $\mathrm{v}$-Ki-ras oncogene alters cAMP nuclear signaling by regulating the location and the expression of cAMP-dependent protein kinase II $\beta$. J. Biol. Chem. 271, 25350-25359

Garrel G., Delahaye R., Hemmings B.A, Counis R., 1995. Modulation of regulary and catalytic subunit levels of cAMP-dependent protein kinase $A$ in anterior pituitary cells in response to direct activation of protein kinases $\mathrm{A}$ and $\mathrm{C}$ or after $\mathrm{GnRH}$ stimulation. Neuroendocrinology 62. $514-522$

Garrel G., Lerrant, Y., Ribot G., Counis R., 1993. Messenger ribonucleic acids for $\alpha$ - and $\beta$-isoforms of cyclic adenosine 3',5'-monophosphate-dependent protein kinase subunits present in the anterior pituitary: regulation of RII $\beta$ and $\mathrm{C} \alpha$ gene expression by the cyclic nucleotide and phorbol ester. Endocrinology 133, 1010-1019

Garrel G., McArdle C.A., Hemmings B.A., Counis R., 1997. Gonadotropin-releasing hormone and pituitary adcnylatc-cyclase activating polypeptide affect levels of cyclic adenosine 3',5'- monophosphate- dependent protein kinase A (PKA) subunits in the clonal gonadotrope $\alpha$ T3-1 cells: cvidence for cross-talk between PKA and protein kinase C pathways. Endocrinology 138,2259 2266

Guild S., Reisine T., 1987. Molecular mechanisms of corticotropin releasing factor stimulation of calcium mobilization and ACTH release from anterior pituitary cells. J. Pharmacol. Exp. Ther. $241,125-130$

Hausken Z.E.. Dell'Acqua M.L., Coghlan V.M., Scott J.D., 1996. Mutational analysis of the kinase A anchoring protein (AKAP)-binding sitc on RII. J. Biol. Chem. 271, 29016-29022

Hirsch A.H., Glantz S.B., Li Y., You Y., Rubin C.S.. 1992. Cloning and expression of an intron-less gene for AKAP-75, an anchor protein for the regulatory subunit of CAMP-dependent protein kinase II $\beta$. J. Biol. Chem, 267, 2131-2134

Inukai T. Wang X., Greer S.E., Greer M.A., 1993. Adenosine 3'.5'-cyclic monophosphate-mediated prolactin secretion in $\mathrm{GH}_{4} \mathrm{C}_{1}$ cells involves $\mathrm{Ca}^{1+}$ intlux through $\mathrm{L}$-type $\mathrm{Ca}^{2+}$ channels. Cell Calcium $14,219-226$

Kurten R.C. Levy L.O., Shey J., Durica J.M., Richards J.S., 1992. Identification and characterization of the GC-rich and cyclic adenosine 3',5'-monophosphate (cAMP)-inducible promoter of the type II $\beta$ cAMP-dependent protein kinase. Mol. Endocrinol. 6, 536-550

Landmark B.F., Fauske B., Eskild W., Skalhegg B., Lohmann S.M., Hansson V., Jahnsen T., Beebe S.J., 1991. Identification, characterization, and hormonal regulation of $3^{\prime}, 5^{\prime}$-cyclic 
adenosine monophosphate-dependent protein kinases in rat Sertoli cells. Endocrinology $129,2345-2354$

Leiser M., Rubin C.S., Erlichman, J., 1986. Differential binding of the regulatory subunits (RII) of cAMP-dependent protein kinase II from bovine brain and muscle to RII binding proteins. J. Biol. Chem. 261. 1904-1908

Lester, L.B., Langeberg L.K, Scott J.D., 1997. Anchoring of protein kinase A facilitates hormonemediated insulin secretions. Proc. Natl. Acad. Sci. USA 94, 14942-14947

Levin N., Roberts J.L., 1991. Positive regulation of proopiomelanocortin gene expression in corticotropes and melanotropes. Front. Neuroendocrinol. 12, 1-22

Li Y., Rubin C.S., 1995. Mutagenesis of the regulatory subunit (RIIb) of cAMP-dependent protein kinase II $\beta$ reveals hydrophobic amino acids that are essential for RII $\beta$ dimerization and/or anchoring RII $\beta$ protein to the cytoskeleton. J. Biol. Chem. 270, 1935-1944

McArdle C.A., Counis R., 1996. GnRH and PACAP action in gonadotropes. Trends Endocrinol. Metab. 7, 1968-175

Meinkoth, J.L., Ji, Y., Taylor, S.S., Feramisco, J.R., 1990. Dynamics of the distribution of cyclic AMP-dependent protein kinase in living cells. Proc. Natl. Acad. Sci. USA 87, 9595-9599

Moore J.J. Baker J.V., Whitsett J.A., 1983. Adenosine 3',5'-monophosphate (cAMP)-binding protein and cAMP-dependent protein kinase in human placenta. J. Clin. Endocrinol. Metab. 56, 1035-1041

Newlon M.G., Roy M., Hausken Z.E., Scott J.D., Jennings P.A., 1997. The A-kinase anchoring domain of type II $\alpha$ cAMP-dependent protein kinase is highly helical. J.Biol.Chem. 272, 23637. 23644

Nigg E.A., Schater G., Hilz. H., Eppenberger H.M., 1985. Cyclic AMP-dependent protein kinase type II is associated with Golgi complex and with centrosomes. Cell 41, 1039-1051

Ostrowska A., 1994. The activation of protein kinase A by cyclic AMP is influenced by oestradiol and progesterone in supernatants from the anterior pituitary but not from hypothalamus of the female rat. Biol. Cell 81. 223-226

Ostrowska A., 2000. The activity of protein kinase A. J. Anim. Feed Sci. 9, 213-246

Ostrowska A., Radzikowska M. Kochman K., 1984. Regulation of protein kinase inhibitors in the anterior pituitary of the female rat. Nueoendocrinol. Lett. 6, 345-350

Ostrowska A., Kochman K., 1990. Effect of estradiol, dibutyryl-cAMP and indomethacin on the protein kinase A inhibitor in the anterior pituitary of ovariectomized rat. Neuroendocrinol. Lett. $12,449-454$

Oyen O., Eskild W., Beebe S.J., Hansson V., Jahnsen T., 1988. Biphasic response to 3'.5'-cyclic adenosine monophosphate (cAMP) at the messenger ribonucleic acid level for a regulatory subunit of cAMP-dependent protein kinase. Mol. Endocrinol. 2. 1070-1076

Przekop F., Stupnicka E., Wolińska-Witort E., Matcusiak K., Sadowski B., Domański E., 1985. Changes in circadian rhythm and suppression of the plasma cortisol level after prolonged stress in sheep. Acta Endocrinol. 110, 540-545

Puttagunta A.L., Chik C.L., Girard M., O'Bricn L., Ho A.K., 1992. Intracellular pH and growth hormone-releasing factor stimulated adenosine 3',5'-monophosphate, intracellular calcium and growth hormone release from rat anterior pituitary cells. J. Endocrinol. 135, 343-352

Ratoosh S.L., Lifka J., Hedin L., Jahnsen T., Richards J.S., 1987. Hormonal regulation of the synthesis and mRNA content of the regulatory subunit of cyclic AMP-dependent protein kinase type II in cultured rat ovarian granulosa cells. J. Biol. Chem. 262, 7306-73!3

Reitherman R., Chen L., Wen S., Harding B.W., 1981. Adenosine 3',5'- monophosphate (cAMP)binding protcins and cAMP-dependent protein kinases in bovine adrenal cortical cell plasma membrane. Endocrinology 109, 301-306 
Rivier C.. Vale W., 1987. Diminished responsiveness of the hypothalamic pituitary adrenal axis of the rat during exposure 10 prolonged stress: a pituitary-mediated mechanism. Endocrinology 121,1320

Roesler W.J., Vandenbark G.R., Hanson R.W., 1988. Cyclic AMP and the induction of cukaryiotic gene transcription. J.Biol. Chem. 263, 9063-9066.

Rubin S.C. 1994. A kinase anchor proteins and the intracellular targeting of signals carried by cAMP. Biochem. Biophys. Acta 1224, 467-479

Singh I.S. Luo Z., Eng A., Erlichman J., 1991. Molecular cloning and characterization of the promoter region of the mouse regulatory subunit RII $\beta$ of type II cAMP-dependent protein kinase. Biochem. Biophys. Res. Commun. 178, 221-226

Skalhegg B.S., Tasken K., Hansson V.. Huitfeldı H.S., Jahnsen T., Lea T., 1994. Location of cAMPdependent protein kinase type I with TCR-CD3 complex. Science 263, 84-87

Srivastava R.K., Lee Y.N., Noguchi K., Park Y.G., Ellis M.J.C., Jeong J-S., Kim S.N., Cho-Chung Y.S., 1998. The RIIß regulatory subunit of protein kinase A binds to cAMP response element: an alternative cAMP signaling pathway. Proc Natl. Acad. Sci. USA 95, 6687-6692

Sundberg D.K., Fawcett C.P., McCann S.M., 1976. The involvement of cyclic-3'.5'-AMP in the release of hormones from the anterior pituitary in vitro. Proc. Soc. Exp. Biol. Med. 151, 149154

Therkauf W.E., Vallee R.B., 1982. Molecular characterization of the cAMP-dependent protein kinase bound to microtubule-associated protein 2. J. Biol. Chem. 257, 3282-3290

\section{STRESZCZENIE}

\section{Jak aktywność kinazy bialkowej A może być zmieniana pod wplywem stresu}

Badano wpływ stresu na wiązania [ $\left.{ }^{3} \mathrm{H}\right] \mathrm{cAMP}$ we frakcji membran i cytosolu 7. przednich części przysadek mózgowych nicestralnych owicc. Frakcje inkubowano z [ $\left.{ }^{3} \mathrm{H}\right] \mathrm{c} \Lambda \mathrm{MP}(10-200 \mathrm{nM})$. Związany ligand izolowano przez. wytrącanic siarczanem amonu i odsączanie na filtrach Millipore. Wiązania $\left[{ }^{3} \mathrm{H}\right] \mathrm{c} A M P$ occniano poprzez analizę Scatcharda. Stała dysocjacji $\left(\mathrm{K}_{\mathrm{D}}\right)$ wiązania [ $\left.{ }^{3} \mathrm{H}\right] \mathrm{cAMP}$ wynosiła $29,13 \pm 3,41 \mathrm{nM}$ we frakcji membran i $21,2 \pm 2,0 \mathrm{nM}$ we frakcji cytosolu. Jednodniowy stres powodował ponad dwukrotne obniżenie wartości $\mathrm{K}_{\mathrm{D}}$ we frakcji membran; po przedłużeniu stresu do trzech ini $K_{0}$ wzrastała do wartości kontrolnych. Stres nie wptywał na $K_{D}$ wiązania [ $\left.{ }^{3} \mathrm{H}\right] \mathrm{c} \Lambda \mathrm{MP}$ do frakcji cytosolu. Maksymalna aktywność wiązania $\left(\mathrm{B}_{\max }\right)\left[{ }^{3} \mathrm{H}\right] \mathrm{cAMP}(148,4 \pm 12,0 \mathrm{pmol})$ byla trzykrotnic więks7a we frakcji membran niż w cytosolu $(45,00 \pm 1,25 \mathrm{pmol} / \mathrm{przys}$ adkę $)$. Jednodniowy stres powodował obniżenie $\mathrm{B}_{\max }\left[{ }^{3} \mathrm{H}\right]$ cAMP w obu frakcjach. Po przedtużeniu stresu do trzech dni wartośc $\mathrm{B}_{\operatorname{mix}}$ wzrastała do wartości kontrolnej. Wyniki te wskazują, żc aktywność kinazy białkowej A w przysadce mózgowej i jej zawartość mogą być modyfikowane poprzez zmiany powinowactwa podjednostki regulacyjnej enzymu do $\mathrm{CAMP}$. 